\title{
PERSPECTIVES ON INTERNATIONAL LEGAL PROTECTION FOR ENVIRONMENTAL REFUGEES
}

\author{
PERSPECTIVAS DA PROTEÇÃO JURÍDICA INTERNACIONAL DOS REFUGIADOS \\ AMBIENTAIS
}

\section{PERSPECTIVAS DE LA PROTECCIÓN JURÍDICA INTERNACIONAL DE LOS REFUGIADOS AMBIENTALES}

\begin{abstract}
ViVIANE PASSOS Gomes
Doutora em Direito Público com ênfase em Gestão das Águas pela Universidad de Sevilla. Possui Diploma de Estudos Avançadas pela Universidad de Sevilla (2012). Mestre em Direito Ambiental com foco em Política Ambiental pela Universidade do Estado do Amazonas. Universidad Castilla-La Mancha (UCLM, Espanha). http://lattes.cnpq.br/0090838513716544 / http://orcid.org/0000-0002-8921-3082 / vipgomes@hotmail.com
\end{abstract}

Diana Cristina de Medeiros Viveiros Graduada em Direito pela Universidade do Estado do Amazonas (2009), com habilitação em Direito Internacional, $e$ em Administração pela Universidade Federal do Amazonas (2009). É mestranda em Estudos Estratégicos da Defesa e da Segurança Internacional, na Universidade Federal Fluminense. (Niterói, Rio de Janeiro, Brasil). http://lattes.cnpq.br/8976183573178984 / http://orcid.org/0000-0001-7145-7022 / dcmviveiros@hotmail.com

\begin{abstract}
The lack of international legal protection of migrants that come from environmental disasters reflects a strong resistance from the international community to create a specific category of "environmental refugees". These gaps contrast with the current international scenario, where there is a growing demand for recognition of the specific rights of this group of people. This article aims to demonstrate a general overview of the so-called environmental refugees' conditions, the perspectives of international legal protection, and the normative progress that, although scarce, do not exempt the need for specific normative protection. The methodology was based on the documents and reports of international organizations and specialized websites. It is a qualitative analysis associated with documentary data and references. Although the concept of "environmental refugees" is not recognized by the United Nations, some progress can already be seen both within the framework of Intergovernmental Organizations and of Civil Society. On the other hand, the need for effective international action, be it through adaptive and temporal measures, such as the use of existing human rights instruments, or be it specific and consolidated through the creation of a specific statute for this new category of refugees is urgent and unavoidable.
\end{abstract}

Keywords: environmental refugees; international legal protection; normative progress perspective.

RESUMO

As lacunas normativas de proteção aos migrantes advindos de catástrofes e desastres ambientais demonstram grande resistência da comunidade internacional quanto à criação de uma categoria específica de "refugiados ambientais". Essas lacunas contrastam com o atual cenário internacional, onde há uma demanda cada vez maior para o reconhecimento dos direitos específicos a esse grupo de pessoas. Esse artigo tem como objetivo demonstrar o panorama geral e as perspectivas de proteção jurídica internacional destinada aos chamados "refugiados ambientais", bem como os avanços normativos que, embora tímidos, não eximem a necessidade de uma proteção normativa específica. A metodologia utilizada baseou-se nos documentos e relatórios de organizações internacionais e sites especializados, através de uma análise qualitativa associada ao levantamento de dados documentais e referências. Embora o conceito de "refugiados ambientais" não seja reconhecido pelas Nações Unidas, alguns avanços já podem ser observados tanto no âmbito das Organizações Intergovernamentais, como no âmbito da Sociedade Civil. Por outro lado, a necessidade de uma ação internacional efetiva, seja através de medidas adaptativas e temporais, como o uso dos instrumentos de direitos humanos existentes, seja ela específica e consolidada através da criação de um estatuto específico para esta nova categoria de refugiados é urgentes e inevitável.

Palavras-chave: refugiados ambientais; proteção jurídica internacional; perpectiva de progresso normativo. 


\section{RESUMEN}

Las lagunas normativas de protección a los migrantes provenientes de catástrofes y desastres ambientales demuestran gran resistencia de la comunidad internacional en cuanto a la creación de una categoría específica de "refugiados ambientales". Estas lagunas contrastan con el actual escenario internacional, donde hay una demanda cada vez mayor para el reconocimiento de los derechos específicos a ese grupo de personas. Este artículo tiene como objetivo demostrar el panorama general y las perspectivas de protección jurídica internacional destinada a los llamados "refugiados ambientales", así como los avances normativos que, en tonos tímidos, no eximen la necesidad de una protección normativa específica. La metodología utilizada se basó en los documentos e informes de organizaciones internacionales y sitios web especializados, a través análisis cualitativo asociado a la recopilación de datos y referencias documentales. Aunque el concepto de "refugiados ambientales" no sea reconocido por las Naciones Unidas, algunos avances ya pueden ser observados tanto en el marco de las Organizaciones Intergubernamentales, como en el ámbito de la Sociedad Civil. Por otro lado, la necesidad de una acción internacional efectiva, sea a través de medidas adaptativas y temporales, como el uso de los instrumentos de derechos humanos existentes, sea específica y consolidada a través de la creación de un estatuto específico para esta nueva categoría de refugiados, es urgente e inevitable.

Palabras clave: refugiados ambientales; protección jurídica internacional; perpectiva de progreso normativo.

\section{CONTENTS}

INTRODUCTION; 1 CURRENT OVERVIEW OF THE ENVIRONMENTAL REFUGEES' SCENARIO; 1.1 General Data on Refugees; 1.2 Environmental Refugees and the Scarcity of Official Data; 2 CURRENT PERSPECTIVE ON THE INTERNATIONAL PROTECTION OF ENVIRONMENTAL REFUGEES; 2.1 UNHCR Humanitarian Help for Environmental Refugees; 2.2 Environmental Refugees and Humanitarian aid: International Meetings and Other Organizations; CONCLUSION; REFERENCES.

\section{INTRODUCTION}

Cross-border displacement induced by environmental events and the lack of international standardization in support of the legal protection of environmental refugees are instigating debates in the international arena. This situation implies not only the need for human rights protection, but also the need for specific international legal protection of this group of people suffering the devastating impacts of major environmental disasters, especially those stemming from climate change.

In this article, the term "environmental refugee" is used to describe this group of people because, although the term is not widely accepted internationally, it has historically been used by several authors. The "environmental refugees" terminology is therefore the first major issue related to the topic, followed by the need for definition and classification already proposed by other authors.

In the international legal protection framework, there is a normative vacuum of specific protection for this group of people. The United Nations High Commissioner for Refugees (UNHCR) resists refering to those displaced by environmental disasters as refugees. Such resistance also 
ISSN 1981-3694

(DOI): $10.5902 / 1981369427260$

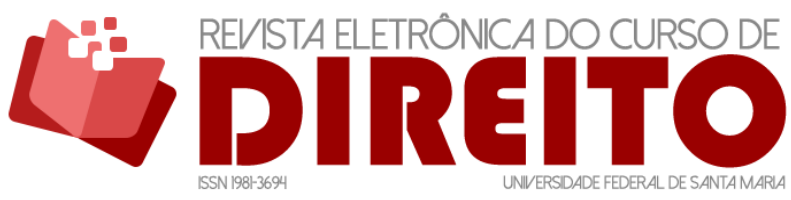

PERSPECTIVES ON INTERNATIONAL LEGAL PROTECTION FOR ENVIRONMENTAL REFUGEES

Viviane Passos Gomes Diana CRISTINA DE MEDEIROS VIVEIROS

arises from the legal limitations imposed by the traditional concept of refugees, provisions of the Convention Relating to the Status of Refugees of 1951. However, at the regional level there are already glimpses of some important initiatives.

It happens, however, that such a legal gap can not be an obstacle to the protection and guarantee of the rights of those who were forced to move from their place of origin or residence. The present situation and projections about the numbers affected by the catastrophic effects related to environmental disasters, especially climate change, is expected to increase considerably in the coming years, as forecast by the United Nations (UN), based on the report "Climate Change 2014 - Impacts, aAdaptation, and vVulnerability", from the Intergovernmental Panel on Climate Change (IPCC), and the data and reports from international agencies dealing with displacement, such as The Internal Displacement Monitoring Centre (IDMC).

International society is not inert to the situation. Several international organizations and non - governmental organizations have been active in promoting the protection of the rights of so-called "environmental refugees". In this context, it is worth mentioning the role of the International Organization for Migration (IOM), the United Nations Office for Disaster Risk Reduction (UNISDR), the United Nations Development Programme (UNDP), the International Committee of the Red Cross (ICRC), other regional organizations, and others of a non governmental characteristic, beyond the UNHCR itself.

There are several international meetings and documents that predispose the recognition of the need for attention to the situation of environmental refugees. In this context, it is noteworthy that some international meetings have dealt directly with the subject, as was the case of the World Humanitarian Summit in 2016. Other initiatives are also worth mentioning, such as the Nansen Initiative. Moreover, a significant milestone was the Paris Agreement, signed during the United Nations Climate Change Conference, COP-21, held in 2015. The document brings the need to protect human rights and calls upon the international community to prevent, minimize and discuss displacement as a result of the adverse effects of climate change. The Paris agreement came into force in November 2016 and has been ratified by 144 countries, however, a possible turning point has threatened the agreement's effectiveness, considering a pledge by now-US President Donald Trump to withdraw the USA from the agreement. In November 2016, a COP-22 was held in Marrakesh, which brought to an international community a regulatory perspective of the Paris Agreement, so that it could be put into practice.

The aim of this article is therefore to expose the main data and projections on the situation of environmental refugees in the world, the legal basis, the actions that were implemented and the prospects of international legal protection for environmental refugees. 
ISSN 1981-3694

(DOI): $10.5902 / 1981369427260$

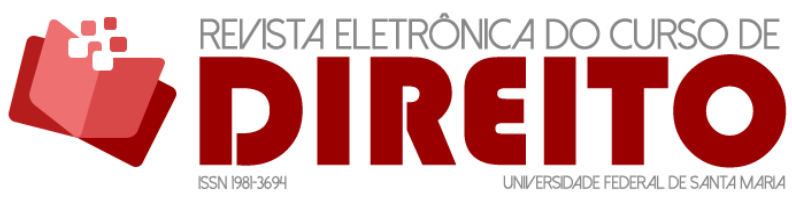

PERSPECTIVES ON INTERNATIONAL LEGAL PROTECTION FOR ENVIRONMENTAL REFUGEES

ViVIANE PASSOS Gomes Diana CRISTINA DE MEDEIROS VIVEIROS

Although "environmental refugees" are not legally recognized as refugees, there are a number of human protection mechanisms that will be addressed in this article.

In order to illustrate some data about "environmental refugees", reports dealing with the subject were consulted, especially those direcly connected to international organizations that deal with it, such as the UNHCR Global Trend Report and the UNHCR Projected Global Resettlement Needs 2017, the IDMC Grid Report 2016, and World Disaster Report 2015, from the International Federation of Red Cross. Other related documents were source of this article, such as the Paris Agreement, the Nansen Agenda, and the Sendai Framework for Disaster Risk Reduction 2015-2030. That said, this was mainly a research based on documents and international instruments. Moreover, the research considers a qualitative methodology, not only with exploratory nature, but also a propositive one, reviewing and exploring specialized reports and documents that provided data about the context of the situation of "environmental refugees" and their vulnerability, especially the legal and normative framework.

Resistance to taking responsibility for refugees is gradually being replaced by the need to resolve the current immigration crisis that, according to the UN, is the worst since World War II. In this context, environmental refugees are not included, but the prospect is that this situation is going to be transformed in the medium or long term. The fact is that there is a huge demand to change this situation in favor of the legal status of environmental refugees, and this requires not only recognition, but also the willingness of the international community even if such change is not envisioned in the short term. The road ahead is still long, but it is already being built and it is this prospect that will be demonstrated throughout this article.

The first part of this article presents an overview of the current situation of refugees' crises, considered the worse after World War II. Moreover, we described some general data about the current situation of "environmental refugees", emphasizing the lack of available data. In the second part, the main humanitarian actions and initiavies in order to protect this group of people were identified, concluding that although there is no specific protection for "environmental refugees", there are actions and iniciatives achieved. Finally, the conclusion and future perspectives were indicating that specific measures should be taken in order to enhance protection of this group of people.

\section{CURRENT OVERVIEW OF THE ENVIRONMENTAL REFUGEES' SCENARIO}

\subsection{General Data on Refugees}


ISSN 1981-3694

(DOI): $10.5902 / 1981369427260$

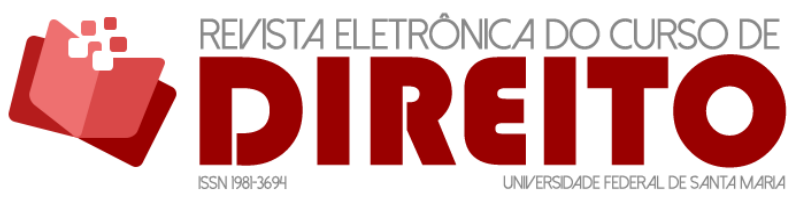

PERSPECTIVES ON INTERNATIONAL LEGAL PROTECTION FOR ENVIRONMENTAL REFUGEES

Viviane Passos Gomes Diana CRISTINA DE MEDEIROS VIVEIROS

According to UNHCR, in the report "Global Trends: forced displacement in 2015", the number of displaced persons in the world was 65.3 million at the end of 2015, of which 21.3 million are refugees, 40.8 million are internally displaced, and 3.2 million are asylum seekers. These displacements were caused by persecution, conflict, violence or human rights violations. Syrians, Afghanis and Somalians make up 54\% of refugees under the mandate of UNHCR $^{1}$. Such data does not include internally displaced persons resulting from environmental disasters, only those who have moved because of conflict.

According to this report, in 2015, there were 2.45 million individual applications for asylum or refugee status submitted to the States or to UNHCR in 174 countries or territories, representing an increase of about 48\% compared to 2014 (1.66 million). This has been the largest number of requests registered by UNHCR².

Germany received the most new asylum applications, about 441,900, during 2015, which corresponds to more than double the previous year. The second largest was the United States of America, with 172,700 applications, an increase of $42 \%$ over the previous year. Sweden was third, with 154,400 new applications, more than double the previous year, followed by Russia, with a total of 152,500 requests $^{3}$.

More than 1.18 million decisions on individual asylum applications were rendered by States and UNHCR during 2015. This does not include the cases closed for administrative reasons, totaling more than 1 million reported to UNHCR. On the one hand, some 672,200 asylum seekers were recognized as as refugees and 243,400 have some form of complementary international protection. On the other hand, about 491,900 asylum applications were rejected ${ }^{4}$.

According to the Report UNHCR Projected Global Resettlement Needs 2017, released in June 2016, over the past decade more than 1 million refugees were submitted by UNHCR to reassetlement to more than 30 countries. In 2015, the acceptance by countries willing to receive refugees reached a record of 134,044 , which is $29 \%$ more than in 2014 . The countries that most received refugees were the United States, accounting for about $62 \%$ of the total, accepting

\footnotetext{
${ }^{1}$ UNITED NATIONS HIGH COMISSIONER FOR REFUGEES - UNHCR. Global Trends: Forced displacement in 2015. Geneva: UNHCR, 2016. p.3.

2 UNITED NATIONS HIGH COMISSIONER FOR REFUGEES - UNHCR. Global Trends: Forced displacement in 2015. Geneva: UNHCR, 2016. p.38.

${ }^{3}$ UNITED NATIONS HIGH COMISSIONER FOR REFUGEES - UNHCR. Global Trends: Forced displacement in 2015. Geneva: UNHCR, 2016. p.38.

${ }^{4}$ UNITED NATIONS HIGH COMISSIONER FOR REFUGEES - UNHCR. Global Trends: Forced displacement in 2015. Geneva: UNHCR, 2016. p.43.
} 
ISSN 1981-3694

(DOI): $10.5902 / 1981369427260$

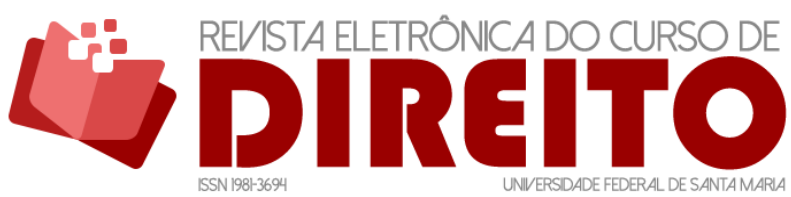

PERSPECTIVES ON INTERNATIONAL LEGAL PROTECTION FOR ENVIRONMENTAL REFUGEES

ViVIANE PASSOS Gomes Diana CRISTINA DE MEDEIROS VIVEIROS

about of 82,491 requests, followed by Canada $(22,886)$, Australia $(9,321)$, Norway $(3,806)$ and the United Kingdom $(3,622)^{5}$.

Despite the increase in the quota of acceptance in the countries receiving refugees, the global resettlement need remains higher than its availability. UNHCR estimates that about 1.19 million people will need resettlement by 2017 . This represents a $3 \%$ increase over the projection for the previous year, about 1.15 million. Syria represents about $40 \%$ of the cases in need of resettlement, Sudan (11\%), Afghanistan (10\%) and the Democratic Republic of Congo (9\%). ${ }^{6}$ Again, these data do not address environmental refugees, only refugees from conflict.

Data and projections regarding conflict refugees are monitored directly by UNHCR, since it is related to its mandate, which makes those data more concrete in compairison to the environmental refugee data. As we shall see below, the UNHCR has exercised humanitarian protection activities for environmental refugees, but still shows a great resistance to embracing such a group of people, which may stem from the impossibility of receiving in its activities an even larger number of people, increasing more than twice their need for expansion.

Given the current refugee crisis, the biggest since the Second World War, according to the United Nations, UNHCR has not agreed to recognize this category of migrants as refugees. Thus, to embrace a new category of refugees, technical and financial adjustments would be necessary within UNHCR, in order to allow the proper international protection for refugees, whether from environmental disasters or conflicts.

\subsection{Environmental Refugees and the Scarcity of Official Data}

Estimate data on Environmental Refugees is a challenge for organizations that deal with the topic. Plenty of official data are missing, and also there are many confused, unreliable and even conflicting estimates on the subject. However, some official agencies on climate change have tried to eliminate this lack by detailing some data that contribute to the current understanding of the environmental refugees' situation in the world.

The United Nations University (UNU), through the Institute for Environment and Human Security, estimated in 2005 that by 2010 there would be about 50 million "environmental

\footnotetext{
${ }^{5}$ UNITED NATIONS HIGH COMISSIONER FOR REFUGEES - UNHCR. UNHCR Projected: Global Resettlement Needs 2017. Geneva: UNHCR , June 2016. p.11.

${ }^{6}$ UNITED NATIONS HIGH COMISSIONER FOR REFUGEES - UNHCR. UNHCR Projected: Global Resettlement Needs 2017. Geneva: UNHCR , June 2016. p.13.
} 
refugees"7 . According RAMOS ${ }^{8}$, "UNU experts estimate that by the year 2050 there will be 200 million people", however, the organization makes it clear that there is no reliability in the estimates and highlights the difficulty in knowing the reasons for migration and the lack of official data ${ }^{9}$. While forecasts estimate between 25 million and 1 billion environmental migrants by 2050 , the number of 200 million is the most cited ${ }^{10}$.

According to the United Nations Office for Disaster Risk Reduction (UNISDR) ${ }^{11}$, climate change-related disasters account for over $80 \%$ of all disasters and are responsible for the displacement of both short and long term ${ }^{12}$. Specifically, the latest data released by this office warned that "in 2015, 92\% of the 98.6 million people affected by 346 disasters faced natural phenomena such as droughts, floods and storms associated with climate ${ }^{* 13}$.

\footnotetext{
7 UNITED NATION UNIVERSITY - UNU. As Ranks of “Environmental Refugees" Swell Worldwide, Calls Grow for Better Definition, Recognition, Support. Tokyo: Presse Release - Institute for Environment and Human Security - UNU, October, 2005. p.1.

${ }^{8}$ RAMOS, Érika Pires. Refugiados Ambientais: em busca de reconhecimento pelo Direito Internacional. Tese (Doutorado) - Faculdade de Direito, Universidade de São Paulo, São Paulo, 2011, p.22.

${ }^{9}$ There are no reliable estimates of the number of people on the move today or in the future as a result of environmental factors. The reason for this is twofold: a difficulty untangling the reasons for migration and a lack of official figures on within country movement. Oftentimes places that experience climate stressors are also affected by conflict situations, political instability, low levels of economic development and human rights abuses. This makes it difficult to establish a direct causal link between the movement of people and the environment. The environment, including climate change impacts, is usually one of multiple factors involved in a person's decision to leave their home. UNITED NATION UNIVERSITY - UNU. 5 facts on climate migrants. Institute for Environment and Human Security, UNU, November, 2015. Available at: < http://ehs.unu.edu/blog/5-facts/5-facts-on-climate-migrants.html>. Accessed: 26 apr.
} 2017.

${ }^{10}$ According to IOM, "Future forecasts vary from 25 million to 1 billion environmental migrants by 2050, moving either within their countries or across borders, on a permanent or temporary basis, with 200 million being the most widely cited estimate." INTERNATIONAL ORGANIZATION FOR MIGRATION - IOM. A complex Nexus. Available at: <http://www.iom.int/complex-nexus\#estimates>. Accessed: 18 apr. 2017.

11 The United Nations Office for Disaster Risk Reduction (UNISDR) was stablished in 1999 to facilitate the implementation of the international strategy for disaster reduction. It is mandated by the United Nations General Assembly Resolution (56/195).

12 THE UNITED NATIONS OFFICE FOR DISASTER RISK REDUCTION - UNISDR. Ten-year review finds $87 \%$ of disasters climate-related. March, $2015 . \quad$ Available at: <http://www.unisdr.org/archive/42862?utm_source=twitter\&utm_medium=post\&utm_term=displacemen migration\&utm_campaign $=$ Climate\&_surl_=lgeuK\&_ots__ $1426239558931 \& \_s t e p \_=1>$. Accessed: 18 apr. 2017.

${ }_{13}$ According to UNISDR, “The 2015 disaster killed 22,773 people. (...) Last year, the greatest impact disasters, taking into account the number of people affected, but not necessarily dead, were dried, whose number reached 32 . These severe droughts reached 50.5 million individuals. The 152 floods occurred in the past year were the second most devastating disaster, killing 3,310 people and affecting other 27,500,000. In addition to these disasters, 90 storms struck Asia and the Pacific. (...) On a global scale, the storms killed 996 people and affected 10.6 million only in 2015. In the last decade were recorded 17,778 deaths associated with this weather phenomenon, affecting 34.9 million people." ORGANIZAÇÃO DAS NAÇÕES UNIDAS NO BRASIL. Desastres associados ao clima foram os mais devastadores em 2015, alerta escritório da ONU. 2016. ONU, February, 2016. Available at: <https://nacoesunidas.org/desastresassociados-ao-clima-foram-os-mais-devastadores-em-2015-alerta-escritorio-da-onu/>. Accessed: 18 apr. 2017. 
ISSN 1981-3694

(DOI): $10.5902 / 1981369427260$

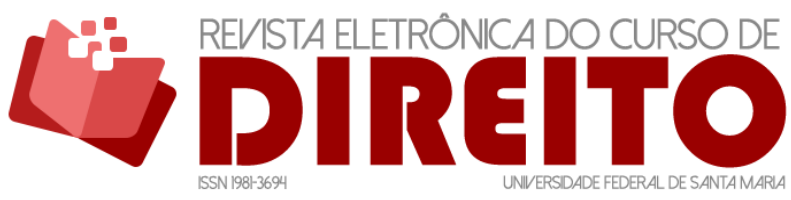

PERSPECTIVES ON INTERNATIONAL LEGAL PROTECTION FOR ENVIRONMENTAL REFUGEES

Viviane Passos Gomes Diana CRISTINA DE MEDEIROS VIVEIROS

The World Disaster Report 2015, from the International Federation of Red Cross, is an important document that gathers information about the recorded disasters and people affected by disasters. Between 2005 and 2014, the total number of natural disasters recorded by the report was 3,809, including both sudden disasters, especially floods, and slow disasters, for example, resulting from drought ${ }^{14}$. The number of people affected was $1,934,754$ the number of people killed was $764,204^{15}$.

The IPCC also warns of the effects of climate change on people's displacement. In a Projection held in its fifth report, the IPCC says that in the 21st century, there will be an increase in prospective displacement due to climate change, especially in developing countries $^{16}$. It is necessary to reduce the vulnerability of this population, enabling effective responses and durable solutions in both cases, in the short or long-term.

With regard to projections, the IPCC estimates that by 2100 , hundreds of millions of people could be affected by coastal flooding and will be displaced due to loss of land. Most of the affected are in East, Southeast and South Asia ${ }^{17}$. The flooding of land resulting from the rise in sea level puts at risk the small islands and island nations, such as Tuvalu, Kiribati, Vanuatu, Fiji, Micronesia and the Solomon Islands.

According to the Report Small Island Developing States (SIDS) in Numbers - Climate Change $2015^{18}$, the United Nations Office of the High Representative for the Least Developed

14 INTERNATIONAL FEDERATION OF RED CROSS AND RED CRESCENT SOCIETIES - IFRC. World Disaster Report 2015 - Focus on local actors, the key to humanitarian effectiveness. Geneva: IFRC, 2015. p.224226.

15 Ibidem, p. 230.

${ }^{16}$ INTERGOVERNAMENTAL PANEL ON CLIMATE CHANGE - IPCC. Summary for policemakers. In: [Field, C.B., V.R. Barros, D.J. Dokken, K.J. Mach, M.D. Mastrandrea, T.E. Bilir, M. Chatterjee, K.L. Ebi, Y.O. Estrada, R.C. Genova, B. Girma, E.S. Kissel, A.N. Levy, S. MacCracken, P.R. Mastrandrea, and L.L. White (eds.)] Climate Change 2014: Impacts, adaptation, and vulnerability. Part A: Global and sectoral aspects. Contribution of Working Group II to the Fifth Assessment Report of the Intergovernmental Panel on Climate Change. Cambridge: University Press, 2014. p.20.

17 INTERGOVERNAMENTAL PANEL ON CLIMATE CHANGE - IPCC. Summary for policemakers. In: [Field, C.B., V.R. Barros, D.J. Dokken, K.J. Mach, M.D. Mastrandrea, T.E. Bilir, M. Chatterjee, K.L. Ebi, Y.O. Estrada, R.C. Genova, B. Girma, E.S. Kissel, A.N. Levy, S. MacCracken, P.R. Mastrandrea, and L.L. White (eds.)] Climate Change 2014: Impacts, adaptation, and vulnerability. Part A: Global and sectoral aspects. Contribution of Working Group II to the Fifth Assessment Report of the Intergovernmental Panel on Climate Change. Cambridge: University Press, 2014. p. 364.

${ }^{18}$ According to the United Nations Office, "SIDS are a distinct group of 38 UN Member States and 20 NonUN Members/Associate Members of regional commissions facing unique social, economic and environmental vulnerabilities. The three geographical regions in which SIDS are located are the: Caribbean, Pacific, and the Atlantic, Indian Ocean and South China Sea (AIMS). SIDS were recognized as a special case both for their environment and development at the 1992 United Nations Conference on Environment and Development held in Rio de Janeiro, Brazil.". UN OFFICE OF THE HIGH REPRESENTATIVE FOR THE LEAST DEVELOPED COUNTRIES, LANDLOCKED DEVELOPING COUNTRIES AND SMALL ISLAND 
ISSN 1981-3694

(DOI): $10.5902 / 1981369427260$

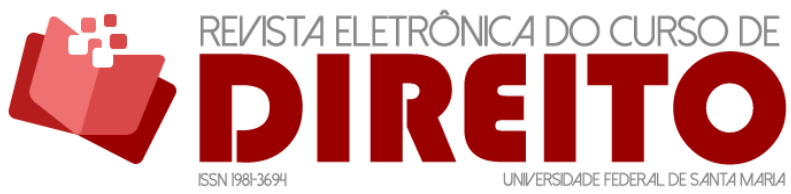

PERSPECTIVES ON INTERNATIONAL LEGAL PROTECTION FOR ENVIRONMENTAL REFUGEES

Viviane Passos Gomes Diana CRISTINA DE MEDEIROS VIVEIROS

Countries, Landlocked Developing Countries and Small Island Developing States (UN-OHRLLS) ${ }^{19}$, SIDS with the highest percentage of land area within 5 meters above sea level are: Tuvalu, Marshall Islands, Kiribati and Cooke Islands. SIDS with the highest percentage of population living within 5 meters above sea level are: Tuvalu, Marshall Islands, Kiribati and Suriname. Therefore, the rise in sea level is one of the biggest threats to SIDS, which may be located in low - lying coastal areas, where the dangers of climate change are very serious for their population. In addition, about $90 \%$ of SIDS are located in areas prone to quickstart weather events, such as floods. SIDS population together already exceeded 66 million and is it projected to reach almost 82 million by $2040^{20}$.

According to the IDMC Report Grid 2016 - Global Report on Internal Displacement, between 2008 and 2015, there were 203.4 million displacements for environmental disasters (an average 25.4 million per year), about 172.3 million (85\%) are related to weather events and 31.1 million (15\%) come from geophysical events ${ }^{21}$.

In 2015, the IDMC reported 27.8 million new displacements caused by conflict, violence, and disasters. Of these, the number of displaced persons associated with conflict and violence was 8.6 million in 28 countries and the number of displacements resulting from natural disasters was 19.2 million in 113 countries, the main regions were East Asia and the Pacific (44\%), South Asia (41\%), Latin America and the Caribbean (8\%) and sub-Saharan Africa (6\%). In 2015, countries with the highest number of new displacements resulting from environmental disasters were India (3.7 million) and China (3.6 million) ${ }^{22}$.

This same report also states that most of the 2015 environmental displacements were caused by climatic events such as floods and storms, which together totaled 14.7 million. Geological phenomena were also highlighted, with about 4.5 million displacements, whose emphasis was given to the earthquake in Nepal, the third country with the largest number

DEVELOPING STATES. Small Islands Developing States in Numbers: Climate Change Edition. Geneva: UN OHRLLS, 2015. p.5.

${ }^{19}$ The United Nations Office of the High Representative for the Least Developed Countries, Landlocked Developing Countries and the Small Island Developing States (UN-OHRLLS) was established by the United Nations General Assembly in 2001 through its resolution 56/227 with functions recommended by the Secretary-General in paragraph 17 of his report A/56/645. UN OFFICE OF THE HIGH REPRESENTATIVE FOR THE LEAST DEVELOPED COUNTRIES, LANDLOCKED DEVELOPING COUNTRIES AND SMALL ISLAND DEVELOPING STATES. About UN-OHRLLS. Available at: <http://unohrlls.org/about-un-ohrlls>. Accessed: 28 apr. 2017.

${ }^{20}$ UNITED NATIONS - UN. Population and Sustainable Development of Small Island Developing States: Challenges, Progress made and Outstanding Issues - Technical Paper No. 2013/4. New York: UN, 2013. p.5.

21 INTERNAL DISPLACEMENT MONITORING CENTRE - IDMC. Grid 2016: Global Report on Internal Displacement. Geneva: IDMC, 201. p.20.

22 INTERNAL DISPLACEMENT MONITORING CENTRE - IDMC. Grid 2016: Global Report on Internal Displacement. Geneva: IDMC, 2016. p.25. 
ISSN 1981-3694

(DOI): $10.5902 / 1981369427260$

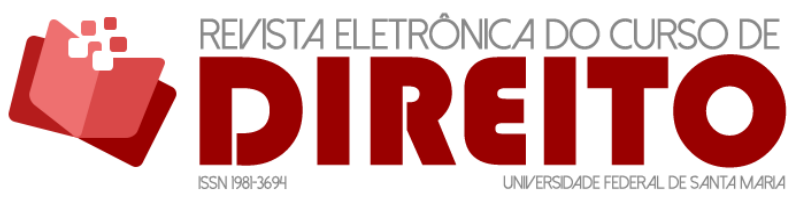

PERSPECTIVES ON INTERNATIONAL LEGAL PROTECTION FOR ENVIRONMENTAL REFUGEES

ViVIANE PASSOS Gomes Diana CRISTINA DE MEDEIROS VIVEIROS

of displacements resulting from environmental disasters, about 2.6 million people, losing only to India and China ${ }^{23}$.

Droughts also cause environmental disasters and displacement, limiting conditions of life, power, water, agriculture, livestock and other basic human needs. According to the IDMC, the measurement of the population displaced by drought is influenced by multifactorial traits and their subsequent effects. It is not possible, therefore, to dissociate it from other issues such as social, demographic, political and economic factors. In such cases, it is important to regularly monitor, long-term impacts, especially on food security. The report also highlights the impact of El Niño on drought and agriculture, between 2015 and 2016, which were more strongly felt in Africa, Central America and the Caribbean, and Pacific areas. Sub-Saharan Africa is particularly susceptible to disasters resulting from drought, considering that about $60 \%$ or its population live in rural areas. ${ }^{24}$

The lack of consolidated data on "environmental refugees" is in contrast with the certainty of the need for international action to protect their rights. Reliable data on the number of internally and cross - border displaced persons requires joint action among the states that suffer the disaster, the states receiving the displaced people, and an international agency to coordinate all this organized information ${ }^{25}$. The gaps in those numbers are also due to the difficulty of knowing exactly how many millions of people have been affected by natural disasters such as earthquakes, floods, hurricanes, and others. Their need for resettlement is urgent. The future expectations of gradual migration, such as the rise in sea level, desertification and drought, are also very difficult to measure.

The UNHCR itself does not mention in its report the latest data on refugees and displaced persons resulting from environmental disasters. This lack of information may reflect

\footnotetext{
${ }^{23}$ In absolute terms, in 2015, in Latin America, Chile was the only country to rank among the ten most responsible for internal displacement, as well as Malawi, Sub-Saharan Africa. Other examples are the typhoons in the Philippines, the cyclone in Myanmar, earthquakes and floods in Pakistan. In the context of environmental shifts, the small Pacific islands are also suffering devastating impacts. In relative terms, Tuvalu and Vanuatu were the most impacted, considering the number of shifts per 100 thousand inhabitants. In this regard, Chile, Paraguay and Dominica, Latin America and the Caribbean are also among the 10 most affected countries. INTERNAL DISPLACEMENT MONITORING CENTRE - IDMC. Grid 2016: Global Report on Internal Displacement. Geneva: IDMC, 2016. p. 20-21.

24 INTERNAL DISPLACEMENT MONITORING CENTRE - IDMC. Grid 2016: Global Report on Internal Displacement. Geneva: IDMC, 2016. p.50- 55.

25 This divergence is also referenced in RAMOS: "The United Nations University, whose public warning issued in 2005 lifted the issue of "environmental refugees" to the global concern condition, has been more cautious in dealing with the issue because of the fact that research on the topic is still in early stages, including on the gathering of statistical data, pointing out the disparity in recent estimates made by experts and international organizations. In RAMOS, Érika Pires. Refugiados Ambientais: em busca de reconhecimento pelo Direito Internacional. Tese (Doutorado) - Faculdade de Direito, Universidade de São Paulo, São Paulo, 2011, p.63.
} 
ISSN 1981-3694

(DOI): $10.5902 / 1981369427260$

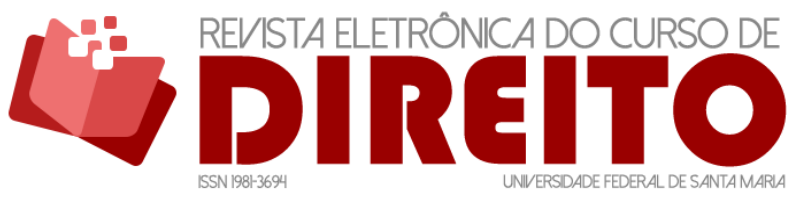

PERSPECTIVES ON INTERNATIONAL LEGAL PROTECTION FOR ENVIRONMENTAL REFUGEES

ViVIANE PASSOS GOMES DiANA CRISTINA DE MEDEIROS VIVEIROS

the non - recognition by the UNHCR and the international community itself of this category of refugees, which makes it difficult to understand the real situation of these people, as well as limiting the actions that should be taken for their resettlement.

For the statistics related to internal displacement resulting from environmental disasters, UNHCR recommends accessing the IDMC report ${ }^{26}$, which has a key role in the global monitoring and analysis of internal displacement around the world.

\section{CURRENT PERSPECTIVE ON THE INTERNATIONAL PROTECTION OF ENVIRONMENTAL REFUGEES}

The main actions taken in favor of protecting environmental refugees rights and the perspectives related by the international community, not only through states, such as in International Organizations, but also through civil society, include the aspects of the international protection of the human beings ${ }^{27}$ which are: human rights, humanitarian law and refugee law.

\subsection{UNHCR Humanitarian Help for Environmental Refugees}

Under the protection of international refugee law, the United Nations, notably the UNHCR, has been fundamental in assisting and relieving many harmful effects of the lack of legal and regulatory protection of environmental refugees.

Despite the absence of protection for environmental refugees in the 1951 Convention and in the New York Protocol of 1967, the UNHCR has been working to guarantee the minimum protection of their rights. Recognition of the need to international protection contrasts, however, with the body's resistance to the inclusion of a category of "environmental refugees": “(...) the UNHCR, which despite openly recognizing the seriousness and complexity of the

\footnotetext{
${ }^{26}$ The Internal Displacement Monitoring Centre (IDMC), has been recognized and endorsed by the United Nations General Assembly Resolutions since 1998. It is part of the Norwegian Refugee Council (NCR), an independent, non-governmental humanitarian organisation.

27 TRINDADE, Cançado; PEYTRIGNET, Gérard; SANTIAGO, Jaime Ruiz de. As Três Vertentes da Proteção Internacional dos Direitos da Pessoa Humana. San José/Brasília: Instituto Interamericano de Direitos Humanos; Comitê Internacional da Cruz Vermelha; Alto Comissariado das Nações Unidas para os Refugiados, 1996. p.117.
} 
ISSN 1981-3694

(DOI): $10.5902 / 1981369427260$

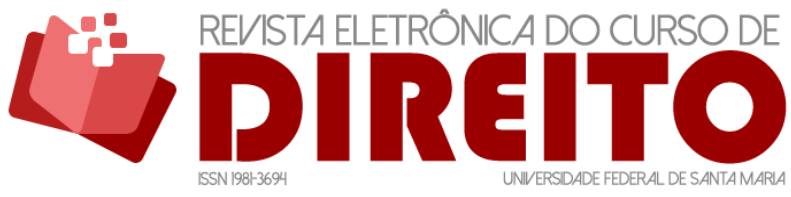

PERSPECTIVES ON INTERNATIONAL LEGAL PROTECTION FOR ENVIRONMENTAL REFUGEES

Viviane Passos Gomes Diana CRISTINA DE MEDEIROS VIVEIROS

environmental factors that generate the flows of migrants and refugees and the fine distinction between the two categories, does not recognize this category as "refugee". ${ }^{28}$

Some actions of UNHCR can be cited for refugees arising from environmental disasters. In this sense, says CLARO ${ }^{29}$ that "in the theme of "environmental refugees", UNHCR has granted protection to a growing number of these migrants in order to reach pragmatic solutions for the effective protection of people who are not entitled to international protection in treaties, and also are not under the agency mandate. It should be noted that UNHCR remains without considering "environmental refugees" as conventional refugees, but it has, over the years, provided assistance to these migrants for humanitarian reasons, respect for human rights and the principle of non-refoulement ."

Luchino and Ribeiro $^{30}$ also analyzed the role of UNHCR in the protection of environmental refugees by conducting an analysis of the agency's performance during the period between 2007 and 2014. According to the authors, 2007 was the year in which UNHCR would have abandoned its neutrality in the face of the subject. Furthermore, in this year there were expressions of concern by the High Commissioner on the impact of the five megatrends on displacement, one of which consisted of Climate Change. In 2008, all UN Agencies were urged to work on Climate Change and Displacement at the request of the Secretary-General of the United Nations.

Emphasis has been given to the Nansen initiative, launched in 2012, on the initiative of the governments of Norway and Switzerland, with unequivocal support from UNHCR, aimed at achieving consensus among States on the best way to address displacement resulting from disasters and climate change, whose agenda focuses on state and regional practices. ${ }^{31}$

This initiative establishes a set of good practices, soft law, with non-binding aspects to vinculate states to protect the needs of environmental refugees. The role of UNHCR in this

\footnotetext{
${ }^{28}$ RAMOS, Érika Pires. Refugiados Ambientais: em busca de reconhecimento pelo Direito Internacional. Tese (Doutorado) - Faculdade de Direito, Universidade de São Paulo, São Paulo, 2011, p. 86.

29 CLARO, Carolina de Abreu Batista. O Aporte Jurídico do Direito dos Refugiados e a Proteção Internacional dos Refugiados Ambientais. In: CARVALHO RAMOS, André; RODRIGUES, Gilberto; ALMEIDA, Guilherme Assis de (Orgs). 60 anos de ACNUR: perspectivas de futuro. São Paulo: ACNUR/ ANDHEP/ CL-A, 2011. p. 256.

${ }^{30}$ RIBEIRO, Wagner Costa. LUCHINO, Maria de las Mercedes Rodriguez Fontan. Refugiados ambientais e a atuaçãoo do ACNUR como organismoo internacional de proteção. Revista Eletrônica do Curso de Direito da UFSM. v. 11, n. $3 / 2016$ p. 897. Available at: <https://periodicos.ufsm.br/revistadireito/article/view/22071/pdf>. Accessed: 09 sep. 2017.

31 ORGANIZAÇÃO NAÇÕES UNIDAS NO BRASIL. ACNUR e 110 países se comprometem a ajudar deslocados por desastres e mudanças climáticas. ONU, October, 2015. Available at: <https://nacoesunidas.org/acnur-e-110-paises-se-comprometem-a-ajudar-deslocados-por-desastres-emudancas-climaticas/>. Accessed: 30 mar. 2017.
} 
ISSN 1981-3694

(DOI): $10.5902 / 1981369427260$

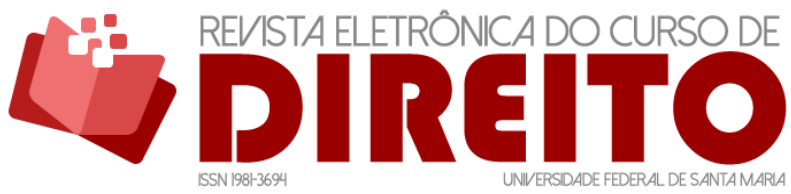

PERSPECTIVES ON INTERNATIONAL LEGAL PROTECTION FOR ENVIRONMENTAL REFUGEES

Viviane Passos Gomes Diana CRISTINA DE MEDEIROS VIVEIROS

initiative takes place through consultations, support and guidance to governments to ensure the prevention, planning and risk management in the event of disasters. It is also worthy of noting the civil society participation, especially in regional consultations convened by the Nansen initiative.

The Nansen Agenda for the protection of cross-border displaced people in the context of climate disasters and changes resulted from this initiative, completed during the Global Consultation Nansen Initiative, held in $2015^{32}$. The non-binding agreement is intended to protect refugees coming from environmental disasters, such as earthquakes, hurricanes, typhoons, floods, droughts and rising sea level. ${ }^{33}$

The cross - border issue typical of the mobility of environmental refugees has been a great challenge because it requires the acceptance of other States in the reception of victims of disasters. Unlike "environmental refugees", UNHCR's mandate includes the protection of Internally Displaced People (IDPs). Some examples could be given in this context, such as UNCHR's action on assistance for the victims of floods and cyclones which occurred in Myanmar, the earthquake victims in Nepal and resettlement of some 50,000 refugees affected by the floods in Ethiopia in $2015^{34}$.

In summary, together with the humanitarian community, UNHCR promotes the debate and the attention to disaster risk reduction and emergency response. As for the protection policies for people who are not directly under its mandate, UNHCR guarantees protection through arrangements between agencies, and it also promotes the dialogue and concerted action between national, regional and international legal arrangements. UNHCR promotes discussions and partnerships regarding displacement induced by climate change. ${ }^{35}$ However, it is observed that this body is limited to recommending sub-regional regulatory agreements and state practice, rather than prioritizing a binding convention on the subject ${ }^{36}$.

\footnotetext{
${ }^{32}$ THE NANSEN INITIATIVE. Global Consultation Conference Report. Geneva: The Nansen Initiative, December, 2015.

${ }^{33}$ UNITED NATIONS - UN. UN Refugees agency backs plan to boost protection for people fleeing disaster and climate change. October, 2015.2 Available <http://www.un.org/apps/news/story.asp?NewsID=52283\#.V8Xh9JgrLIV> Accessed: 30 mar. 2017.

${ }^{34}$ UNITED NATIONS HIGH COMISSIONER FOR REFUGEES - UNHCR. The Environment \& Climate Change. Geneve: UNHCR, October, 2015. p. 9.

35 ALTO COMISSARIADO DAS NAÇÕES UNIDAS PARA REFUGIADOS (ACNUR). O ACNUR e as Mudanças Climáticas: envolvimento, desafios e respostas. Available at: <http://www.acnur.org/portugues/oacnur/envolva-se/eventos/acnur-na-rioplus20/mudancas-climaticas-perguntas-e-respostas/> Accessed: 30 mar. 2017.

${ }^{36}$ UNITED NATIONS HIGH COMISSIONER FOR REFUGEES - UNHCR. The Environment \& Climate..., Op. Cit.
} 
ISSN 1981-3694

(DOI): $10.5902 / 1981369427260$

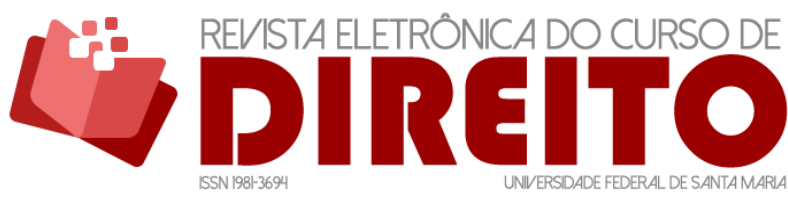

PERSPECTIVES ON INTERNATIONAL LEGAL PROTECTION FOR ENVIRONMENTAL REFUGEES

Viviane Passos Gomes Diana CRISTINA DE MEDEIROS VIVEIROS

\subsection{Environmental Refugees and Humanitarian aid: International Meetings and Other}

\section{Organizations}

The UNISDR also has an important role in prevention and disaster risk management, allowing that forced displaced from environmental impacts are, when unavoidable, better managed so that the humanitarian costs are reduced.

In this context, the Sendai Framework for Disaster Risk Reduction 2015-2030 is noteworthy, approved during the Third United Nations Conference Disaster Risk Reduction, held in Sendai in 2015. This document has reinforced that between 2008 and 2014, 144 million people have been displaced by disasters and many disasters were exacerbated by climate change.

The Sendai Framework also strengthens human rights as guiding principles of its application. Its four priority areas are ${ }^{37}$ : understanding disaster risk, strengthening disaster risk governance to manage disaster risk, investing in disaster risk reduction for resilience and enhancing disaster preparedness for effective response and to rebuild better in recovery, rehabilitation and reconstruction.

In regard to disaster victims and forced displacement, the document also proposes regular exercise preparedness, response and recovery in order to ensure rapid and effective response to disasters and related displacement, including access to shelter, food and supplies ${ }^{38}$.

Another recent milestone toward the protection of environmental refugees took place during the United Nations Climate Change Conference, COP-21, held in Paris in 2015. The Paris Agreement, recognizing climate change as a concern of humankind, mentions protection of human rights and the rights of migrants in its preamble. Furthermore, it urges the organizations and bodies outside the Convention to form a task force to "develop integrated recommendations for integrated approaches to prevent, minimize and address displacement related to the adverse impacts of climate change." 39

The COP-21 in Paris and the COP-22 in Marrakesh promote the continuity of the review process of the so-called Warsaw International Mechanism, regarding the losses and damages associated with the impacts of climate change, whose objective is to reduce and prevent the

\footnotetext{
${ }^{37}$ THE UNITED NATIONS OFFICE FOR DISASTER RISK REDUCTION - UNISDR. Sendai Framework for Disaster Risk Reduction 2015- 2030. Geneve: UNIDRS, March, 2015. p.4.

${ }^{38}$ THE UNITED NATIONS OFFICE FOR DISASTER RISK REDUCTION - UNISDR. Sendai Framework for Disaster Risk Reduction 2015- 2030. Geneve: UNIDRS, March, 2015. p. 18.

${ }^{39}$ UNITED NATIONS - UN. United Nations Framework Convention on Climate Change: Paris Agreement. November, $2015 . \quad$ Available at: <http://unfccc.int/files/meetings/paris_nov_2015/application/pdf/paris_agreement_english_.pdf> Accessed: 30 mar. 2017. p. 7.
} 
ISSN 1981-3694

(DOI): $10.5902 / 1981369427260$

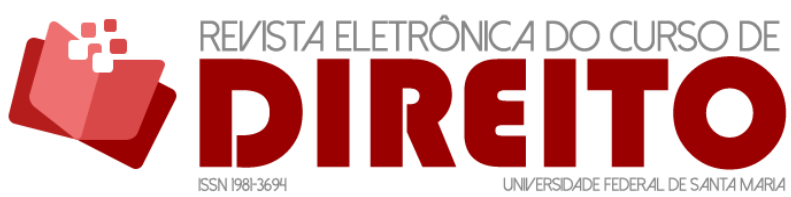

PERSPECTIVES ON INTERNATIONAL LEGAL PROTECTION FOR ENVIRONMENTAL REFUGEES

Viviane Passos Gomes Diana CRISTINA DE MEDEIROS VIVEIROS

displacement of populations and address the issues of displacement, migration and mobility. Article 49 of the Paris Agreement itself calls on the Executive Committee of the Warsaw International Mechanism to establish a clearinghouse for risk transfer, facilitating the efforts of the Parties to develop and implement comprehensive risk management strategies.

In May 2016, during the World Humanitarian Summit in Istanbul, the United Nations Secretary General, Ban Ki-moon, proposed five responsibilities in the report "One Humanity: Shared Responsibility": 1. Global leadership to prevent and end conflict; 2. Uphold the norms that safeguard humanity; 3. Leave no one behind; 4 . Change people's lives - from delivering aid to ending need; 5 . Invest in humanity. ${ }^{40}$

The third responsibility, for example, reinforces the commitment to reduce forced displacement, citing people who live in remote areas, desert, coastal and island states where the effects of climate change are devastating. In this context, the issue of environmental refugees is highlighted, especially when it comes to the need to reduce forced displacement, whether internal or cross - border, as well as promoting additional measures to meet protection and assistance needs.

With respect to environmental refugees, the third responsibility relates to the need to prepare for cross-border forced displacement due to disasters and climate change. It also confirms the necessity for humanitarian protection for those who are not protected by the Convention of Refugees of 1951.

The fifth responsibility relates to the need to change the current financing and investment system on the humanitarian issue, reinforcing the need for risk prevention, for reducing the impact of crises and natural disasters and other emergencies. This Responsibility also encourages the possibility of the United Nations, together with other international financial institutions, to consider co-hosting an international financing platform.

Since 2005, the IOM led, co-led or facilitated coordination and field management activities in 26 countries. The role of the IOM together with other international organizations, non - governmental organizations and national authorities is essential to ensure the human rights of victims of environmental disasters.

According to the International Organization for Migration (IOM) ${ }^{41}$, since the 2000s 750 projects related to environmental migration have been implemented by the organization, to

\footnotetext{
${ }^{40}$ UNITED NATIONS - UN. One Humanity, shared responsibility: Report of the Secretary-General for the World Humanitarian Summit. Geneve: General Assembly A/70/709, feb 2016.

${ }^{41}$ The International Organization for Migration (IOM), created in 1951, is the lead inter-governmental organization in the field of migration and works closely with governmental, intergovernmental and non-
} 
ISSN 1981-3694

(DOI): $10.5902 / 1981369427260$

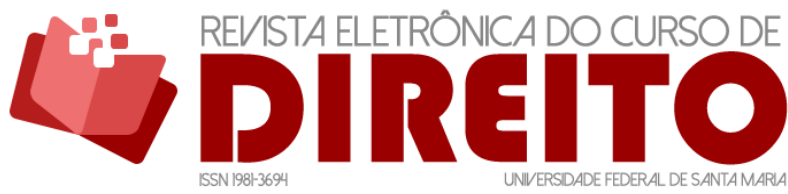

PERSPECTIVES ON INTERNATIONAL LEGAL PROTECTION FOR ENVIRONMENTAL REFUGEES

ViVIANE PASSOS Gomes Diana CRISTINA DE MEDEIROS VIVEIROS

mitigate its effects and propose stable solutions. The OIM's approach to respond to migration resulting from environmental events has three main objectives: 1) to avoid the forced migration resulting from environmental factors; 2) To provide assistance and protection to affected populations; 3) To facilitate migration as an adaptation strategy to climate change and strengthen the resilience of affected communities. In the prevention aspect, the IOM acts in partnership with local communities, promoting interventions in infrastructure, the way of life and mobility as a strategy to build the resilience of countries affected by environmental disasters. For example, the IOM, in partnership with other organizations, provided support to farming communities in Kenya to preserve their model of livestock subsistence, especially after receiving several Somali refugees who came as a result of the drought of 2011. ${ }^{42}$

As for the assistance and protection of affected populations, the IOM has planned reallocations in areas of high risk of disasters and in regions facing high levels of environmental degradation. Despite the difficulties inherent in the relocation, the IOM has some strategies that are conducted in successful ways, such as:

Evaluate coercive (e.g. land-use regulations) and non-coercive (e.g. financial incentives) measures to decrease the concentration of people and assets in the areas at risk. Consider land tenure and property regimes in both the community of origin and the community of destination, in order to avoid conflict and make relocation just. In the case of cross-border relocation, adequately consider the issue of legal status and rights of the relocated population. Ensure that relocated households have sufficient access to resources and services for them to pursue safe lives, by restoring their livelihood options and community life, and by building their knowledge of the new context. Whenever the relocated households' previous assets cannot be restored, provide adequate compensation, taking into account the longer-term consequences of relocation. Make sure both the relocated and the host communities are involved in the decision-making process, in order to better prepare them for change, as well as minimize intracommunal tension. ${ }^{43}$

In preparation for the displacement, the IOM suggests facilitating people's mobility, keeping them out of danger reducing the negative impacts. In this context, the IOM has worked on the education and training of local staff, sometimes in partnership with other organizations,

governmental partners. It has four areas of migration manegement: (1) migration and development, (2) Faciliting migration; (3) Regulating migration, (4) Forced migration.

42 INTERNATIONAL ORGANIZATION FOR MIGRATION - IOM. Operational Responses to Environmental Migration and displacement. In: IOM Outlook on migration, environment and climate change. Geneva: IOM, 2014, p.111-112.

43 INTERNATIONAL ORGANIZATION FOR MIGRATION - IOM. Operational Responses to Environmental Migration and displacement. In: IOM Outlook on migration, environment and climate change. Geneva: IOM, 2014, p. 113. 
ISSN 1981-3694

(DOI): $10.5902 / 1981369427260$

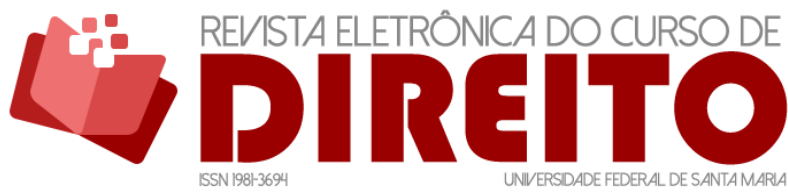

PERSPECTIVES ON INTERNATIONAL LEGAL PROTECTION FOR ENVIRONMENTAL REFUGEES

ViVIANE PASSOS GOMES DIANA CRISTINA DE MEDEIROS VIVEIROS

as was the case of Mozambique (2013), Colombia and Namibia ${ }^{44}$. In times of disaster, the IOM aims to ensure adequate humanitarian assistance and basic needs, as well as transporting and keeping people safe.

Civil society is constantly carrying out humanitarian actions for the victims of environmental disasters. In this context, the role of the International Humanitarian Law (IHL) is extended to environmental refugees. According to COSTA:

International humanitarian laws that currently apply to situations of armed conflict $(\ldots)$ should also respond to and be applied to the case of environmental refugees, who are also victims of the effects caused by climate change and the environmental and social impacts in the world. ${ }^{45}$

The most active civil organization in the field of humanitarian aid is the International Red Cross and the Red Crescent Movement, composed of the International Committee of Red Cross $^{46}$ (ICRC), the International Federation of Red Cross and Red Crescent Societies (IFRC) ${ }^{47}$ and 189 National Societies.

The ICRC's involvement in environmental disaster have been in various activities. About the ICRC's activities, CLARO points out that

A form properly used for the protection of environmental refugees by $\mathrm{IHL}$ is humanitarian assistance, which is held in Article 5 of the ICRC's status: the same governing principles of the IHL are applicable, with the difference that the impartiality, neutrality and impersonality are directed to the protection of people in environmental disaster situations. ${ }^{48}$

\footnotetext{
44 INTERNATIONAL ORGANIZATION FOR MIGRATION - IOM. Operational Responses to Environmental Migration and displacement. In: IOM Outlook on migration, environment and climate change. Geneva: IOM, 2014, p. 115.

45 COSTA, Claudia Silvana da. Refugiados Ambientais, sujeitos em construção pelos efeitos das mudanças climáticas. Revista FAFIBE, n.4, Bebedouro, 2011.

${ }^{46}$ The International Committee of the Red Cross (ICRC) is an independent and neutral organization that provides protection and humanitarian assistance to victims of war and armed violence. INTERNATIONAL FEDERATION OF RED CROSS AND RED CRESCENT SOCIETIES - IFRC. Who we are. Available at: http://www.ifrc.org/en/who-we-are/the-movement/>. Accessed: 27 apr. 2017.

47 The International Federation is a global humanitarian organization that coordinates and directs international assistance in cases of natural or caused by humans in non-conflict situations disaster. Its mission is to improve the lives of vulnerable people by mobilizing the power of humanity. The International Federation is working with National Societies to intervene disaster anywhere in the world. Its relief operations are combined with development activities covering disaster preparedness programs, health and care activities, as well as the promotion of humanitarian values. Ibidem

${ }^{48}$ CLARO, Carolina de Abreu Batista. O Aporte Jurídico do Direito dos Refugiados e a Proteção Internacional dos Refugiados Ambientais. In: CARVALHO RAMOS, André; RODRIGUES, Gilberto; ALMEIDA, Guilherme Assis de (Orgs). 60 anos de ACNUR: perspectivas de futuro. São Paulo: ACNUR/ ANDHEP/ CL-A, 2011. p. 106.
} 
ISSN 1981-3694

(DOI): $10.5902 / 1981369427260$

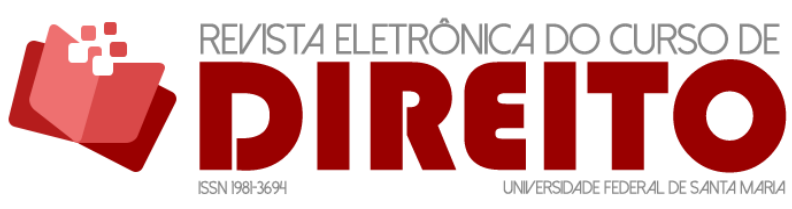

PERSPECTIVES ON INTERNATIONAL LEGAL PROTECTION FOR ENVIRONMENTAL REFUGEES

Viviane Passos Gomes Diana CRISTINA DE MEDEIROS VIVEIROS

The humanitarian work of the International Red Cross Committee in favor of migrants was also synthesized in the brochure "Activities for Migrants", from February 2016. In this brochure, the emphasis of actions is for migrants coming from situations of armed conflict or other situations of violence. Even so, the document stresses that “More than 230 million people around the world are migrants, and the routes they take transcend borders and regions. The causes behind migration are many and varied, often involving a mix of push and pull factors. Whatever the reasons, migrants can become vulnerable at many stages of their journey as they travel from their home countries, often through other countries, to their intended destination. ${ }^{49}$ "Environmental refugees" are thus protected by the ICRC for migrants activities ${ }^{50}$. Among the actions listed in the brochure, under the protection of migrants, are: to talk directly and confidentially with authorities to ensure that states fulfill their obligations to protect the rights of migrants and relieve their suffering; to raise awareness of the IHL and human rights; to promote exchanges with research institutions and help migrant communities through counseling and material support. In the context of migrants held in criminal detention centers, the ICRC verifies the conditions and access to due process of law, including cases where there has been illegal entry in the recipient country. Under the Family Links Network, the ICRC facilitates contact between located disappeared people and their families.It is noteworthy that the ICRC also assists the humane treatment in forensic medicine to ensure fair treatment of deceased migrants, ensuring that their deaths are documented and people are identified and, as far as possible, bodies are repatriated or given proper burials. Finally, it promotes assistance to migrants with the partnership of the National Societies, with supply of drinking water, hygiene, health care and infrastructure and basic sanitation $^{51}$.

The initiatives of the International Federation of Red Cross (IFRC) are based on the 2020 document, whose main objectives are: (1)To save lives, protect livelihoods and strengthen disaster $^{52}$ and crisis recovery; (2) To facilitate safe and healthy life; (3) To promote social

\footnotetext{
${ }^{49}$ INTERNATIONAL COMITEE OF THE RED CROSS - ICRC. Activities for Migrants. Geneva: ICRC, 2016. p.1-2.

${ }^{50}$ According to ICRC, "Migrants are persons who leave or flee their habitual residence to go to new places - usually abroad - to seek opportunities or safer and better prospects. Migration can be voluntary or involuntary, but most of the time a combination of choices and constraints are involved. Thus, this policy includes, among others, labour migrants, stateless migrants, and migrants deemed irregular by public authorities. It also concerns refugees and asylum seekers, notwithstanding the fact that they constitute a special category under international law." In: INTERNATIONAL COMITEE OF THE RED CROSS - ICRC. Activities for Migrants. Geneva: ICRC, 2016, p.2.

${ }^{51}$ INTERNATIONAL COMITEE OF THE RED CROSS - ICRC. Activities for Migrants. Geneva: ICRC, 2016, p. 4-8.

52 The 2020 strategy was adopted by the Federation's General Assembly in November 2009 and results of consultations together with the International Red Cross and Red Crescent. (...) For the IFRC, the main
} 
ISSN 1981-3694

(DOI): $10.5902 / 1981369427260$

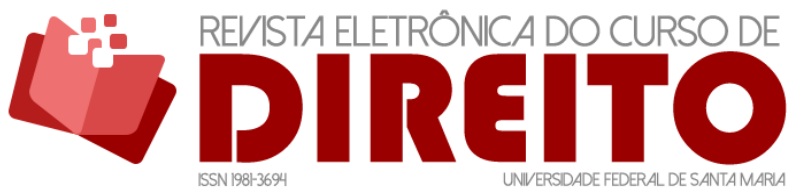

PERSPECTIVES ON INTERNATIONAL LEGAL PROTECTION FOR ENVIRONMENTAL REFUGEES

Viviane PASSOS Gomes Diana CRISTINA DE MEDEIROS VIVEIROS

inclusion and a culture of non - violence and peace. The first two goals ${ }^{53}$ are most directly related to the protection of "environmental refugees".

Also regarding the humanitarian aspects related to the protection of "environmental refugees", it is worth noting the work of the Inter-Agency Standing Committee (IASC). Among its four major priorities for 2016 and 2017 are: 1) Effective Response to Emergency and Protracted Crisis; 2) Accountability and Inclusivity; 3) Displacement and Protection Outcomes; 4) Financing ${ }^{54}$. For each priority, the related activities were defined.

Under the Effective Response to Emergencies and Protracted Crises, the IASC seeks to strengthen the humanitarian response and promote the resilience of sectors. For this, many actions were defined to strengthen the humanitarian development and response system for emergencies. As for the priority "Accountability and Inclusivity", cooperation and transparency with actions and partnership with other non - governmental organizations and other stakeholders is reinforced. Within "Displacement and Protection Outcomes", are the activities aimed at protecting the most vulnerable in emergencies, such as implementing the framework for durable solutions for internally displaced persons, and strengthen the response to humanitarian needs of migrants. Finally, with regard to activities related to the financing, the IASC aims to promote

action to take during disasters is to save lives, reduce human suffering, damage and losses, and protect, comfort and support victims. "A disaster is a serious disruption of the functioning of a community through widespread losses and disruption that exceed its capacity to cope using its own resources. During disasters, due to natural and human-made hazards, or in crises that arise from violent conflicts, the immediate imperative is to save lives, reduce suffering, damage and losses, and to protect, comfort and support affected people. A INTERNATIONAL FEDERATION OF RED CROSS AND RED CRESCENT SOCIETIES IFRC. Strategy 2020: Saving Lives, Changing Minds. Geneva: IRFC, 2010. p.13.

${ }^{53}$ The first objective reinforces the preparation, recovery and disaster management system. In the first case, the preparation starts with the training of volunteers, supply inventories and optimize logistics. The concern is to save as many lives and livelihoods, so it is critical to prevention and early warning systems. As for recovery, the focus is on stabilizing the impacts of disasters, promoting support for physical and mental health and ensuring livelihoods, reducing vulnerability to disasters to come. Finally, disaster management promotes joint work with National Societies to coordinate humanitarian aid. The second one, when related to the perspectives of environmental refugees, has expectations to reduce exposure and vulnerability to natural hazards and caused by human action, and the promotion of a sustainable living environment. For this, the goal is the reduction of disaster risk and combating climate change. In the first case, working together with communities and government is essential to reduce vulnerabilities and promote government policies that encourage risk reduction measures. In the second case, there is the recognition that the impact of climate change and environmental degradation tend to leverage and increase disaster risks. To address this, the proposal is to act through adaptation and mitigation measures, promoting social mobilization, the savings in energy use and the development of sustainable communities. In: A INTERNATIONAL FEDERATION OF RED CROSS AND RED CRESCENT SOCIETIES - IFRC. Strategy 2020: Saving Lives, Changing Minds. Geneva: IRFC, 2010, p.13-15.

54 INTER AGENCY STANDING COMMITTEE - IASC. IASC Priorities. Available at: <https://interagencystandingcommittee.org/about-iasc/iasc-priorities>. Accessed: 10 apr. 2017. 
ISSN 1981-3694

(DOI): $10.5902 / 1981369427260$

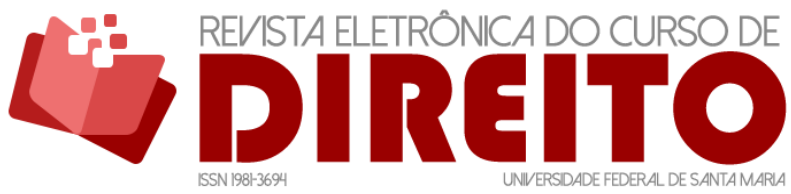

PERSPECTIVES ON INTERNATIONAL LEGAL PROTECTION FOR ENVIRONMENTAL REFUGEES

Viviane Passos Gomes Diana CRISTINA DE MEDEIROS VIVEIROS

counseling for new financing mechanisms, focusing on the effective response to the situation of emergencies. ${ }^{55}$

In 2016, the United Nations Development Programme (UNDP) ${ }^{56}$ held the Global Mapping Initiatives on Migration and Displacement, noting that, since 2011, UNDP has been active in about 125 initiatives related to displacement and 192 initiatives related to migration . In terms of funding volume, the top five displaced programmes for which figures were available were: Nepal, Pakistan, the Democratic Republic of Congo, Haiti and Somalia. As the key donors for both migration and displacement initiatives, there were Japan, the United States, the European Commission, Norway, Switzerland, the United Kingdom and the Central Emergency Relief Fund ${ }^{57}$.

The UNDP broad areas of work in migration and displacement are: 1) Developing comprehensive national policy and institutional frameworks for migration; 2)Managing migration for long-term positive development impacts at the sub-national and local levels; 3) Resiliencebased development solutions for migration and displacement in times of crisis, conflict and disaster ${ }^{58}$. The UNDP's initiatives are related to its expertise in three main areas: livelihoods and inclusive economic growth; governance, rule of law and peacebuilding; and climate change and disaster risk reduction. Within these areas, some activities were highlighted in the report, among which, under the "protection of environmental refugees", stands out as an example the strengthening of resilience in the event of future shocks.

Within the framework of UNDP initiatives designed to support the migration related to climate change and the reduction of disaster risks, carried out in partnership with local actors, is the case of the Drought Recovery Program in Kenya between 2011 and 2014, seeking recovery and disaster risk reduction, and the protection of livelihoods. In terms of cooperation and partnership, the UNDP is in partnership with the IOM, the UNHCR and the World Bank, as well as civil society. It is emphasized that the UNDP has been active in all phases of displacement

\footnotetext{
55 Ibidem.

56 The United Nations Development Programme (UNDP) focuses on helping countries build solutions in three main areas: sustainable development, democratic governance and peacebuilding, climate and disaster resilience. UNITED NATIONS DEVELOPMENT PROGRAMME - UNDP. A world of development experience. Available at: <http://www.undp.org/content/undp/en/home/operations/about_us.html>. Accessed:10 apr. 2017.

${ }^{57}$ UNITED NATIONS DEVELOPMENT PROGRAMME - UNDP. Global Mapping of UNDP Initiatives on Migration and Displacement. Geneva: UNDP, 2016. p. 1.

${ }^{58}$ UNITED NATIONS DEVELOPMENT PROGRAMME - UNDP. Global Mapping of UNDP Initiatives on Migration and Displacement. Geneva: UNDP, 2016, p. 1.
} 
ISSN 1981-3694

(DOI): $10.5902 / 1981369427260$

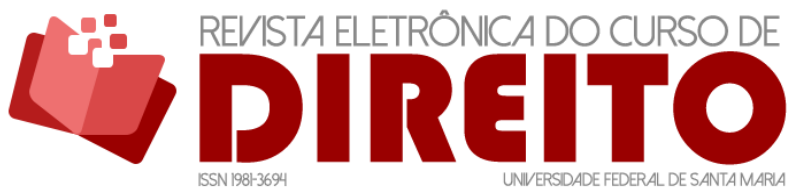

PERSPECTIVES ON INTERNATIONAL LEGAL PROTECTION FOR ENVIRONMENTAL REFUGEES

Viviane Passos Gomes Diana CRISTINA DE MEDEIROS VIVEIROS

reduction, from the projects focused on the prevention and displacement as a result of protracted crises or sudden onset ${ }^{59}$.

In September 2016, the United Nations Summit on Refugees was held in New York. There was some resistance from countries regarding the predisposition to receive new population groups. Many international human rights organizations such as Amnesty International ${ }^{60}$ and Human Rights Watch ${ }^{61}$ viewed with pessimism the performance of some countries.

During the Summit, 193 governments signed the New York Declaration ${ }^{62}$, whose approach to victims of natural disasters was already given in the introduction. The text of the Declaration reinforces the Sendai Framework on reducing disaster risk, the Addis Ababa Agenda and the Paris Agreement on Climate Change. In item 3.10, the countries commitment to provide assistance to migrants who experience conflict and natural disasters appears, working in coordination with local authorities. The item also reinforces the commitment to the Nansen Initiative, already mentioned in this study.

The main highlights of the New York Declaration include the commitments to the protection of human rights for all migrants, regardless of their status, emphasizing the rights of the most vulnerable such as women and children. In addition, the Declaration proposes support to countries receiving large numbers of refugees and migrants. It is noteworthy that an agreement was signed in which the IOM has become part of the United Nations ${ }^{63}$.

The signing of the New York Declaration and the commitments held in 2016 are important steps towards the adoption of a global pact for safe, regular, and orderly migration in 2018. Given this perspective, the expectation is that in 2018 an agreement that prioritizes the protection of migrants could be signed, with common principles and responsibilities shared by all its signatories. In the context of migration, this protection is extremely important for the protection of the rights of "environmental refugees", although it is not a document that gives victims of environmental disasters the same conditions as refugees.

\footnotetext{
${ }^{59}$ UNITED NATIONS DEVELOPMENT PROGRAMME - UNDP. Global Mapping of UNDP Initiatives on Migration and Displacement. Geneva: UNDP, 2016, p. 3-6.

${ }^{60}$ AMNESTY INTERNATIONAL. World leaders have 'shirked, not shared' responsibility on refugee crisis. Available at: <https://www.amnesty.org/en/latest/news/2016/09/world-leaders-have-shirkedresponsibility-on-refugee-crisis/> Accessed: 27 apr. 2017.

${ }^{61}$ FRELICK, Bill. World Refugee Summits Fail Refugees: Commitments Still Needed to Resettle More Refugees. Human Rights Watch, $2016 . \quad$ Available at: <https://www.hrw.org/pt/news/2016/09/21/294433>. Accessed: 27 apr. 2017.

${ }^{62}$ UNITED NATIONS - UN. New York Declaration. UN, September, 2016. Available at: <http://refugeesmigrants.un.org/declaration>. Accessed: 28 apr. 2017.

${ }_{63}$ UNITED NATIONS - UN. New York Declaration. UN, September, 2016. Available at: <http://refugeesmigrants.un.org/declaration>. Accessed: 28 apr. 2017.
} 
ISSN 1981-3694

(DOI): $10.5902 / 1981369427260$

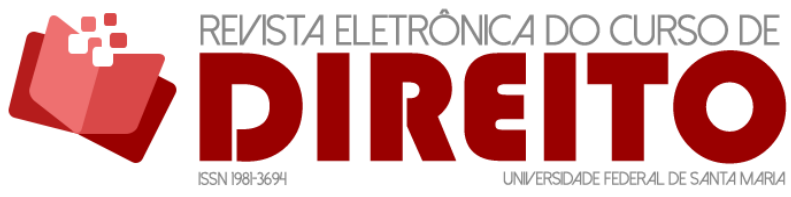

PERSPECTIVES ON INTERNATIONAL LEGAL PROTECTION FOR ENVIRONMENTAL REFUGEES

Viviane Passos Gomes Diana CRISTINA DE MEDEIROS VIVEIROS

Otherwise, humanity could face even worse results related to environmental disasters that could exacerbate the refugees crisis and the number of displaced persons and migrants.

In order to consolidate the prospect of a legally binding document to "environmental refugees" protection, willingness and goodwill by countries to assume international host responsibility, as well as huge change and flexibility as to the concept of extending refugee status to victims of environmental disasters would be necessary. This possibility has not yet been mooted and in the short term, there are no prospects that it will. In the long term, however, there is an expectation that this is going to be normatized, because it already seems to be consolidated in the international arena.

\section{CONCLUSION}

As related in this article, migration due to environmental or economic reasons, or conflict have reached major proportions. The vulnerability of millions of people to climate events has increasingly raised concerns and discussions. There are numerous attempts by international bodies and international civil society to generate publications, hold conferences and meetings to draw attention to the worsening problem, in addition to the important role of humanitarian aid to people affected by disasters caused by climate change.

Even though these are laudable initiatives, they only resulted in statements of principles, essentially declaratory and descriptive, without achieving a real consensus to create uniform international rules, with the ability to oblige states to respect their commitments. Thus, the international protection of these migrants has not evolved satisfactorily, causing millions of people affected by environmental disasters to be deprived of minimum rights for dignified survival.

Even with the difficulty of establishing norms of international law regarding "environmental refugees", the international community can not refrain from promoting all necessary attempts to guarantee the rights of those who have been forced to move within their borders due to natural events.

Although the term "environmental refugee" does not have a predetermined and officially established legal definition, other international legal mechanisms of protection of the human person can and should be applied to safeguard life and ensure better conditions for survival. In this sense, this study addressed the human rights foundations, humanitarian law, refugee law, 
ISSN 1981-3694

(DOI): $10.5902 / 1981369427260$

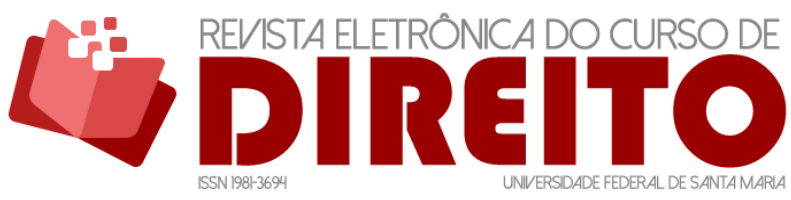

PERSPECTIVES ON INTERNATIONAL LEGAL PROTECTION FOR ENVIRONMENTAL REFUGEES

Viviane Passos Gomes Diana CRISTINA DE MEDEIROS VIVEIROS

international law principles and / or other branches of law, which may prove to be adapted for the protection of the "environmental refugee".

The main actions implemented in order to protect this group of people were also illustrated. The role of initiaves such as The New York Declaration, the Sendai Framework, the Addis Ababa Agenda, and the Paris Agreement on Climate Change are examples on how human rights are being improved in this area. Moreover, international organizations, such as such as UNHCR and UNDP, IOM, ICRC and IASC, are providing practical measures to change this scenario.

Another alternative that has received international support and continues to deserve investment is the negotiation and implementation of a specific international treaty for the protection of "environmental refugees", other than that established by UNHCR Convention of 1951. For this purpose, refugees should be considered protected by the UN Convention. In most cases, Europeans fleeing the difficult conditions that were in their countries ravaged by world wars were represented. Today, the context of refugees is very different and not only covers refugees of conflict, but also "environmental refugees", to which one can not deny the need for specific protection. In short, the context is new and demands new international regulation.

Yesterday's refugees may be today's recipients, moreover, it is not just a political and social debt to the vulnerable, but also a possible environmental debt, because many countries that now refuse to receive "environmental refugees" are industrialized, big polluters, and indirectly responsible for climate change. Dramatic weather events, whether sudden or slow in evolution, in turn, end up affecting the countries "in development" which present socioenvironmental vulnerability, and the population ends up being forced to move to "developed countries".

These states have imposed major restrictions on the reception of environmentally displaced by limiting their internal migration policies, in order to prevent many people from reaching their territories, which would generate disputes for labor and even for natural resources, affecting their economies.

Counteracting all the grounds and reasons raised not only by the vulnerable population, but also by the likely recipient countries is crucial, although the consensus for a modern and coherent solution is not extendable.

It is advised for sovereign states to set limits on the creation and ratification of a Statute on Environmental Refugees, establishing rights and duties of the refugee, ensuring the proper functioning of the internal socio-political arena. It is essential, however, that this new policy embrace migrants from different parts of the globe, without letting a "modus vivendi" annihilate the other. 
ISSN 1981-3694

(DOI): $10.5902 / 1981369427260$

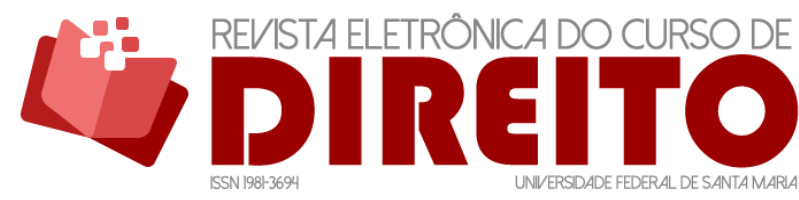

PERSPECTIVES ON INTERNATIONAL LEGAL PROTECTION FOR ENVIRONMENTAL REFUGEES

Viviane Passos Gomes Diana CRISTINA DE MEDEIROS VIVEIROS

The need for effective international action, be it through adaptive and temporal measures, such as the use of existing human rights instruments, or be it specific and consolidated through the creation of a specific statute for this new category of refugees is urgent and unavoidable. Estimates demonstrate rapid growth of migration caused by climate change, which will leave millions of people on the margins of international protection.

\section{REFERENCES}

ALTO COMISSARIADO DAS NAÇÕES UNIDAS PARA REFUGIADOS - ACNUR. O ACNUR e as Mudanças Climáticas: envolvimento, desafios e respostas. Available at:

<http://www.acnur.org/portugues/o-acnur/envolva-se/eventos/acnur-na-rioplus20/mudancasclimaticas-perguntas-e-respostas/> Accessed: 30 mar. 2017.

AMNESTY INTERNATIONAL. World leaders have 'shirked, not shared' responsibility on refugee crisis. Available at: <https://www.amnesty.org/en/latest/news/2016/09/world-leaders-haveshirked-responsibility-on-refugee-crisis/> Accessed: 27 apr. 2017.

CLARO, Carolina de Abreu Batista. O Aporte Jurídico do Direito dos Refugiados e a Proteção Internacional dos Refugiados Ambientais. In: CARVALHO RAMOS, André; RODRIGUES, Gilberto; ALMEIDA, Guilherme Assis de (Orgs). 60 anos de ACNUR: perspectivas de futuro. São Paulo: ACNUR/ ANDHEP/ CL-A, 2011.

COMITÊ INTERNACIONAL DA CRUZ VERMELHA. Atividades em benefícios dos Migrantes. Genebra: CICV, 2016.

COSTA, Claudia Silvana da. Refugiados Ambientais, sujeitos em construção pelos efeitos das mudanças climáticas. Revista FAFIBE, ำ.4, Bebedouro, 2011.

FRELICK, Bill. World Refugee Summits Fail Refugees: Commitments Still Needed to Resettle More Refugees. Human Rights Watch, 2016. Available at:

<https://www.hrw.org/pt/news/2016/09/21/294433>. Accessed: 27 apr. 2017.

INTER AGENCY STANDING COMMITTEE - IASC. IASC Priorities. Available at:

<https://interagencystandingcommittee.org/about-iasc/iasc-priorities>. Accessed: 10 apr. 2017.

INTERGOVERNAMENTAL PANEL ON CLIMATE CHANGE - IPCC. Summary for policemakers. In: [Field, C.B., V.R. Barros, D.J. Dokken, K.J. Mach, M.D. Mastrandrea, T.E. Bilir, M. Chatterjee, K.L. Ebi, Y.O. Estrada, R.C. Genova, B. Girma, E.S. Kissel, A.N. Levy, S. MacCracken, P.R. Mastrandrea, and L.L. White (eds.)] Climate Change 2014: Impacts, adaptation, and vulnerability. Part A: Global and sectoral aspects. Contribution of Working Group II to the Fifth Assessment Report $f$ the Intergovernmental Panel on Climate Change. Cambridge: University Press, 2014.

INTERNAL DISPLACEMENT MONITORING CENTRE - IDMC. Grid 2016: Global Report on Internal Displacement. Geneva: IDMC, 2016. 
ISSN 1981-3694

(DOI): $10.5902 / 1981369427260$

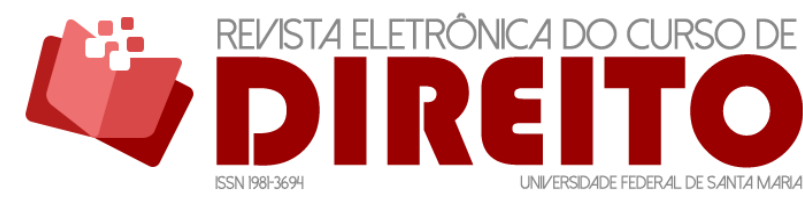

PERSPECTIVES ON INTERNATIONAL LEGAL PROTECTION FOR ENVIRONMENTAL REFUGEES

Viviane Passos Gomes Diana CRISTINA DE MEDEIROS VIVEIROS

INTERNATIONAL COMITEE OF THE RED CROSS - ICRC. Activities for Migrants. Geneva: ICRC, 2016.

INTERNATIONAL FEDERATION OF RED CROSS AND RED CRESCENT SOCIETIES - IFRC. Strategy 2020: Saving Lives, Changing Minds. Geneva: IRFC, 2010.

INTERNATIONAL FEDERATION OF RED CROSS AND RED CRESCENT SOCIETIES - IFRC. Who we are. Available at: < http://www.ifrc.org/en/who-we-are/the-movement/>. Accessed: 27 apr. 2016.

INTERNATIONAL FEDERATION OF RED CROSS AND RED CRESCENT SOCIETIES - IFRC. World Disaster Report 2015: Focus on local actors, the key to humanitarian effectiveness. Geneva: IFRC, 2015.

INTERNATIONAL ORGANIZATION FOR MIGRATION - IOM. A complex Nexus. Available at: <http://www.iom.int/complex-nexus\#estimates>. Accessed: 18 apr. 2017.

INTERNATIONAL ORGANIZATION FOR MIGRATION - IOM. Operational Responses to Environmental Migration and displacement. In: IOM Outlook on migration, environment and climate change. Geneva: IOM, 2014.

ORGANIZAÇÃO NAÇÕES UNIDAS NO BRASIL . ACNUR e 110 países se comprometem a ajudar deslocados por desastres e mudanças climáticas. ONU, October, 2015. Available at:

<https://nacoesunidas.org/acnur-e-110-paises-se-comprometem-a-ajudar-deslocados-pordesastres-e-mudancas-climaticas/>. Accessed: 30 mar. 2017.

ORGANIZAÇÃO DAS NAÇÕES UNIDAS NO BRASIL. Desastres associados ao clima foram os mais devastadores em 2015, alerta escritório da ONU. ONU, February, 2016. Available at:

<https: / / nacoesunidas.org/desastres-associados-ao-clima-foram-os-mais-devastadores-em-2015alerta-escritorio-da-onu/>. Accessed: 18 apr. 2017.

RAMOS, Érika Pires. Refugiados Ambientais: em busca de reconhecimento pelo Direito Internacional. Tese (Doutorado), 2011, 150 pp.

RIBEIRO, Wagner Costa. LUCHINO, Maria de las Mercedes Rodriguez Fontan. Refugiados ambientais e a atuaçãoo do ACNUR como organismoo internacional de proteção. Revista Eletrônica do Curso de Direito da UFSM. v. 11, n. 3 / 2016 p. 890-914. Available at: <https://periodicos.ufsm.br/revistadireito/article/view/22071/pdf>. Accessed: 09 sep. 2017.

THE NANSEN INITIATIVE. Global Consultation Conference Report. Geneva: The Nansen Initiative, December, 2015.

THE UNITED NATIONS OFFICE FOR DISASTER RISK REDUCTION - UNISDR. Sendai Framework for Disaster Risk Reduction 2015- 2030. Geneve: UNIDRS, March,2015.

THE UNITED NATIONS OFFICE FOR DISASTER RISK REDUCTION - UNISDR. Ten-year review finds $87 \%$ of disasters climate-related. March, 2015. Available at:

<http://www.unisdr.org/archive/42862?utm_source=twitter\&utm_medium=post\&utm_term=disp lacement, migration\&utm_campaign=Climate\&_surl_=lgeuK\&_ots_ $=1426239558931 \&$ _step_ =1> . Accessed: 18 apr. 2017. 
ISSN 1981-3694

(DOI): $10.5902 / 1981369427260$

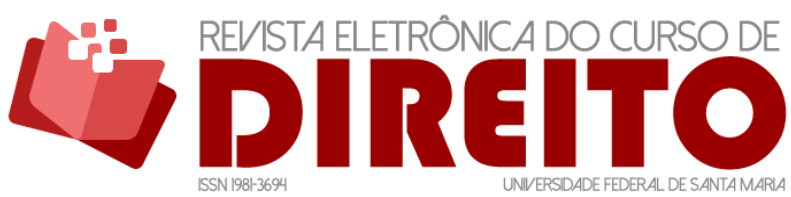

PERSPECTIVES ON INTERNATIONAL LEGAL PROTECTION FOR ENVIRONMENTAL REFUGEES

Viviane Passos Gomes Diana CRISTINA DE MEDEIROS VIVEIROS

TRINDADE, Cançado; PEYTRIGNET, Gérard; SANTIAGO, Jaime Ruiz de. As Três Vertentes da Proteção Internacional dos Direitos da Pessoa Humana. San José/Brasília: Instituto Interamericano de Direitos Humanos; Comitê Internacional da Cruz Vermelha; Alto Comissariado das Nações Unidas para os Refugiados, 1996.

UN OFFICE OF THE HIGH REPRESENTATIVE FOR THE LEAST DEVELOPED COUNTRIES, LANDLOCKED DEVELOPING COUNTRIES AND SMALL ISLAND DEVELOPING STATES. About UN-OHRLLS. Available at: <http://unohrlls.org/about-un-ohrlls>. Accessed: 28 apr. 2017.

UN OFFICE OF THE HIGH REPRESENTATIVE FOR THE LEAST DEVELOPED COUNTRIES, LANDLOCKED DEVELOPING COUNTRIES AND SMALL ISLAND DEVELOPING STATES.Small Islands Developing States in Numbers: Climate Change Edition. Geneva: UN - OHRLLS, 2015.

UNITED NATION UNIVERSITY - UNU. 5 facts on climate migrants. Institute for Environment and Huan Secutity, UNU, November, 2015. Available at: < http://ehs.unu.edu/blog/5-facts/5-factson-climate-migrants.html>. Accessed: 26 apr. 2017.

UNITED NATION UNIVERSITY - UNU. As Ranks of “Environmental Refugees” Swell Worldwide, Calls Grow for Better Definition, Recognition, Support. Tokyo: Presse Release - Institute for Environment and Human Security - UNU, October, 2005.

UNITED NATIONS - UN. New York Declaration. UN, September, 2016. Available at: <http://refugeesmigrants.un.org/declaration>. Accessed: 28 apr. 2017.

UNITED NATIONS - UN. One Humanity, shared responsibility: Report of the Secretary-General for the World Humanitarian Summit. Geneva: General Assembly A/70/709, February, 2016.

UNITED NATIONS - UN. Population and Sustainable Development of Small Island Developing States: Challenges, Progress made and Outstanding Issues - Technical Paper $N^{\circ}$ 2013/4. New York: UN, 2013.

UNITED NATIONS - UN. UN Refugees agency backs plan to boost protection for people fleeing disaster and climate change. October, 2015. Available at:

<http: //www.un.org/apps/news/story.asp?NewsID=52283\#.V8Xh9JgrLIV> Accessed: 30 mar. 2017.

UNITED NATIONS - UN. United Nations Framework Convention on Climate Change: Paris Agreement. November, 2015. Available at:

<http://unfccc.int/files/meetings/paris_nov_2015/application/pdf/paris_agreement_english_.p df> Accessed: 30 aug. 2017.

UNITED NATIONS DEVELOPMENT PROGRAMME - UNDP. A world of development experience. Available at: <http://www.undp.org/content/undp/en/home/operations/about_us.html>. Accessed:10 apr. 2017.

UNITED NATIONS DEVELOPMENT PROGRAMME - UNDP. Global Mapping of UNDP Initiatives on Migration and Displacement. Geneva: UNDP, 2016.

UNITED NATIONS HIGH COMISSIONER FOR REFUGEES - UNHCR. Global Trends: Forced displacement in 2015. Geneva: UNHCR, 2016. 
ISSN 1981-3694

(DOI): $10.5902 / 1981369427260$

UNITED NATIONS HIGH COMISSIONER FOR REFUGEES - UNHCR. The Environment \& Climate Change. Geneve: UNHCR, October, 2015.

UNITED NATIONS HIGH COMISSIONER FOR REFUGEES - UNHCR. UNHCR Projected: Global Resettlement Needs 2017. Geneve: UNHCR, June, 2016.

\section{COMO FAZER A REFERÊNCIA DO ARTIGO (ABNT):}

GOMES, Viviane Passos; VIVEIROS, Diana Cristina de Medeiros. Perspectives on international legal protection for environmental refugees. Revista Eletrônica do Curso de Direito da UFSM, Santa Maria, RS, v. 12, n. 3, p. 937-963, dez. 2017. ISSN 1981-3694. Disponível em: <https://periodicos.ufsm.br/revistadireito/article/view/27260>. Acesso em: dia mês. ano. doi:

http://dx.doi.org/10.5902/1981369427260. 